\title{
Students' Attitudes Towards Career in the Tourism Industry - Implications for Tacit Knowledge Management
}

\section{Marlena A. Bednarska*, Marcin Olszewski **}

\begin{abstract}
The success of tacit knowledge management lies in firms' capabilities to attract and retain employees possessing unique knowledge. The purpose of the paper is to investigate students' attitudes towards career in tourism in the context of tacit knowledge management. The study was conducted on the group of 345 undergraduates and graduates enrolled in tourism and hospitality studies in Poznan. Research revealed that majority of students plan short-term career in tourism, which entails tacit knowledge leakage outside the tourism industry. It was also found that students' attitudes towards tourism careers are significantly influenced by previous work experience and satisfaction with the studies.
\end{abstract}

Keywords: tacit knowledge, management, attitudes, career, tourism industry, students.

\section{Introduction}

Knowledge is becoming widely recognized as an important asset for gaining sustainable competitive advantage (Davenport and Prusak, 1998; Argot and Ingram, 2000), especially in the long term (Gallupe, 2001). According to Nonaka (1991, p. 96) "in an economy where the only certainty is uncertainty, the one sure source of lasting competitive advantage is knowledge". It is crucial how organizations create, acquire, disseminate and use knowledge, and how organizations protect and manage the knowledge they have (Gallupe, 2001).

According to Cooper capturing the tacit knowledge in the tourism industry is one of the major challenges and to date this has not been formally addressed by researchers (2006). Tacit knowledge in the form of skills, knowhow and competences, due to duplication and transfer difficulties, is the most important reason for sustaining and enhancing the competitive position of firms (Ambrosini and Bowman, 2008; da Silva, 2012). Tacit knowledge is gained and shared through practice and observation and without the

\footnotetext{
* Marlena A. Bednarska, Ph.D., Poznan University of Economics, al. Niepodleglości 10, 61-875 Poznań, Poland. m.bednarska@ue.poznan.pl.

** Marcin Olszewski, Ph.D., Poznan University of Economics, al. Niepodleglości 10, 61-875 Poznań, Poland. marcin. olszewski@ue.poznan.pl.
} 
exchange of key personnel it is almost non-transferable (Nonaka, Toyama, and Nagata, 2000). It follows that the acquisition of tacit knowledge requires offering working conditions which will attract and retain workers. Due to significant role of young employees in the tourism industry, it is important to determine the possibilities of acquiring workers entering the labour market by examining students' attitudes towards a career in tourism. Findings of similar research carried out in Europe, Asia, America, and Australia clearly demonstrate that for many tourism and hospitality graduates tourism jobs are short-lived professions. (Kusluvan and Kusluvan, 2000; Barron, Maxwell, Broadbridge and Ogden, 2007; Roney and Öztin, 2007; Dickerson, 2009; Jiang and Tribe, 2009; Richardson, 2010). It would be of value to examine this phenomenon in the Polish context.

The purpose of this paper is to investigate students' attitudes towards career in tourism and to indicate the implications of these attitudes for tacit knowledge management. The paper opens by reviewing the literature on the role of tacit knowledge in the tourism market. Then the findings of the study on the students' perception of the attractiveness of career in tourism and its determinants are presented. Finally, the overall implications and recommendations for future research are proposed and the main conclusions are summarised.

\section{Tacit knowledge as a strategic asset - literature review}

Knowledge is regarded as one of the most important assets for creating and sustaining competitive advantage of the modern enterprises. The focus on resources that are developed within the organization and difficult to imitate puts organizational knowledge in a preeminent position as the principal source of competitive advantage (Argot and Ingram, 2000). Knowledge has been variously defined: as "justified true belief" (Nonaka, 1994, p. 15) or "mixture of framed experience, values, contextual information, and expert insight" (Davenport and Prusak, 1998, p. 5). Knowledge involves human actions and decisions representing interpretation and application of data (Droege and Hoobler, 2003). As data are interpreted and applied, new knowledge is often developed (Baumard, 1999).

The traditional starting point for analysing knowledge is Polanyi's (1966) distinction between codified and tacit knowledge. Codified knowledge is articulated knowledge, which can be specified verbally or in writing such as patents, drawings, concepts or formulas. This feature accounts for its easy and wide dissemination, therefore codified knowledge is less unique to the knowledge holder in terms of creating competitive advantage. In the current era of globalization, everyone has relatively easy access to codified knowledge 
(da Silva, 2012). This kind of knowledge can be exchanged among individuals and organizations in a formalized and relatively simple way (in writing or by using symbols and codes such as block diagrams).

Tacit knowledge, in contrast, is less easily replicated (Leonard and Sensiper, 1998). It exists in the background of consciousness, which Polanyi expressed as "we can know more than we can tell". Leonard and Sensiper (1998, p. 114) added that "we can often know more than we realise". Despite its key role in organization performance, the management of tacit knowledge is still challenging to organizations (Ambrosini and Bowman, 2008). This is due to the tacit knowledge characteristics. According to Zack $(1999$, p. 46) tacit knowledge is "subconsciously understood and applied, difficult to articulate, developed from direct experience, and usually shared through highly interactive conversation, storytelling, and shared experience". It is included in the individual experience and involves personal beliefs, attitudes, values and intuition. People that possess tacit knowledge cannot readily explain the decision rules that underlie their performance (Polanyi, 1966). Tacit knowledge is highly personal and difficult to formalize, making it difficult to communicate. Summing up, tacit knowledge is a resource that can provide sustainable competitive advantage as it meets all the criteria of the resource-based view of the firm: it is valuable, rare, imperfectly substitutable and imitable (Barney, 1991). In the tourism industry the tacit knowledge is particularly valuable because of the nature of the service product, where the service delivery occurs as a result of interaction between customers and employees and where it is required that employees are knowledgeable of customers' needs in order to achieve customer satisfaction (Hallin and Marnburg, 2008).

At least four types of tacit knowledge can be identified in literature: embrained, embodied, encultured, and embedded (Blackler, 1995):

- Embrained knowledge is dependent on conceptual skills and cognitive abilities, it allows recognition of underlying patterns, and reflection on these.

- Embodied knowledge is action oriented and called ,knowledge how'. This knowledge is acquired by doing, and is rooted in specific contexts. This kind of knowledge may include learning from observation or participation in the service process.

- Encultured knowledge refers to the process of achieving shared understandings. Cultural meaning systems are intimately related to the processes of socialization and acculturation; such understandings are likely to depend heavily on language, and hence to be socially constructed and open to negotiation.

- Embedded knowledge resides in systemic routines. The notion of ,embeddedness' was introduced by Granovetter (1985), who 
proposed a theory of economic action that would neither be heavily dependent on the notion of culture (i.e. be ,oversocialized') nor heavily dependent on theories of the market (i.e. be ,under-socialized'). His idea was that economic behaviour is intimately related to social and institutional arrangements.

The complex nature of valuable tacit knowledge makes its acquisition very difficult (Kogut and Zander, 1992) as it is embodied in organizational members, tools, tasks and networks. Moreover, "tacit knowledge cannot be captured, translated, or converted, but only manifested, in what we do" (Tsoukas, 2003, p. 426). Thus, this kind of knowledge can be acquired only through hands-on experience or learning-by-doing (Almeida and Kogut, 1999; Zucker, Darby and Armstrong, 1998; Filatotchev, Liu, Lu and Wright, 2011). For instance, in hotel organizations, a major part of frontline personnel's domain-specific knowledge is developed due to their interactions with guests, managers, colleagues, suppliers, employees of competing hotels and other external interest groups on a regular basis (Hallin and Marnburg, 2008). The tacit knowledge can be effectively transferred through human mobility (Kaj, Pekka and Hannu, 2003; Song, Almeida and Wu, 2003; Filatotchev et al., 2011). Thus, it is more apt to be lost through employee turnover, when employees leave, companies lose not only human capital, but also accumulated knowledge (Droege and Hoobler, 2003). Companies seeking to acquire tacit knowledge must have the ability to attract human capital, and retention of the tacit knowledge embedded in employees' mind requires offering attractive working conditions.

The possibilities of attracting and retaining suitable employees who are holders of tacit knowledge in tourism stem from the image of the industry held by hospitality and tourism students. The literature on the attractiveness of tourism job attributes contrasts negative and positive characteristics. Among its positives are glamour, the opportunity to travel, meeting people, foreign language use, and task variety, good atmosphere and co-operation with colleagues, as well as prospects for internationally based careers (Szivas, Riley and Airey, 2003; Hjalager, 2003). The negatives include unfavourable remuneration level, limited promotion opportunities, low social status, unfavourable physical working environment, incompetency of management, and poor treatment by supervisory staff (Jiang and Tribe, 2009; Kusluvan and Kusluvan, 2000; Richardson, 2010; Richardson and Butler, 2012; Duncan, Scott and Baum, 2013).

Such negative images may provide reasons why so many employees do not identify the tourism and hospitality industries as a 'career choice' but rather as a 'stop gap' whilst looking for 'something better' (Richardson, 2009; Duncan et al., 2013). 


\section{Hypotheses and research method}

Tacit knowledge is argued to be critical to a firm's capacity to generate and sustain competitive advantage, but a particularly important issue for tourism organisations is how to attract people possessing this tacit knowledge. Many studies have found that students did not believe an employment in the sector would offer them the factors they found important in their job choice. In consequence, they do not plan to purse a job in tourism upon graduation or consider tourism jobs as the first stepping stone to a career elsewhere and leave the industry within a few years (King, McKercher, and Waryszak, 2003; Lu and Adler, 2009; Jiang and Tribe, 2009; Richardson, 2010; Richardson and Butler, 2012). Leaving the industry is connected with knowledge outflow, which is particularly acute due to the loss of valuable tacit knowledge which cannot be easily and quickly recovered. As a result, the tacit knowledge acquired during studies and first years of work is leaking out of the tourism sector. The consequences of this leakage include loss of the training costs and the time spent on coaching these workers. Moreover, the staff turnover hampers the possibilities for development of knowledge because staffs who already have other plans for their working life than a career in tourism are unlikely to have adequate motivation to contribute to development processes in the firm (Hjalager, 2002).

One of the factors that affects the propensity to work in tourism is previous work experience. Many studies recognize the relevance of previous experiences to the decision to take up and to continue career in the tourism industry. Most of them indicate that the negative image of the industry held by hospitality and tourism students appears to be developed with the increase in the exposure to working life in the industry through a part-time employment and student placements (Kusluvan and Kusluvan, 2000; Jiang and Tribe, 2009; Richardson, 2010). According to Barron and Maxwell the more exposure students have to the hospitality industry, the less commitment they demonstrate (1993).

It is also interesting to determine the relationship between perception of tourism studies and a propensity to work in the tourism industry. Birdir (2002, after: Roney and Öztin, 2007) surveyed tourism students in Turkey in order to find out the reasons why some students were not eager to work in the industry after graduation. The main reason they stated was the lack of quality education in tourism to enable them to be successful in the sector.

The aim of this research is to investigate students' attitudes towards career in the tourism industry and its determinants in the knowledge management context. Specifically, this research tries to ascertain to what extend perceived attractiveness of tourism employment, previous experiences and study satisfaction can influence the propensity to treat the hospitality and tourism 
industry as a long-term career sector. On the basis of literature review the following hypotheses are developed.

- H1: Low attractiveness of tourism employment perceived by students deteriorates the willingness to undertake a long-term career in tourism.

- H2: Work experience in the tourism industry deteriorates the willingness to undertake a long-term career in tourism.

- H3: The negative experience with the studies deteriorates the willingness to undertake a long-term career in tourism.

The target population of the present study comprised undergraduates and graduates enrolled in tourism and hospitality studies in universities in Poznan. Eight public and private higher education institutions offered bachelor and master degrees in tourism in 2012 and a total of 4150 students took tourism and hospitality courses. To obtain a representative subset of the target population a single-stage cluster sampling was employed. The sample size was determined based on statistical precision approach - assuming the confidence level at $95 \%$, the desired precision at $5 \%$, and the degree of variability at $50 \%$, and applying the finite population correction produced the minimum sample of 352 respondents.

A measurement instrument was developed based on a review of the literature and previous studies on attitudes of students towards a career in the tourism industry, namely Kusluvan and Kusluvan (2000), Blomme, van Rheede and Tromp, (2009), Bednarska and Olszewski (2010), Richardson and Butler (2012). The questionnaire consisted of four main components. Participants were requested first to envisage an ideal employer and rate a range of 16 items displaying various dimensions of working conditions based on their expectations. In the second section they were asked to assess the analysed attributes regarding employers in the tourism industry. The data enabled to compute the gaps between preferred and perceived job/organisation attributes***. Section three sought information about respondents' willingness to pursue careers in the tourism industry. In the last section students reported their age, gender, year of study, study mode, study degree, attitude to tourism studies, and work experience. The inquiry form contained closed-ended questions, for gradations of opinions a sevenpoint Likert scale was used, ranging from "strongly disagree" (1) to "strongly agree" (7).

Data was collected through group-administered questionnaires distributed during a regularly scheduled class period. A total of 353 participants were recruited for the study. Due to incomplete or incoherent information

*** The gap was calculated as a difference between expectation and perception for desired attributes and as a difference between perception and expectation for undesired attribute, thus a positive number represents a negative situation (unmet expectations). (Bednarska and Olszewski, 2010). 
8 questionnaires were excluded, which resulted in 345 usable questionnaires for further analysis. The sample was demographically diverse. Participants ranged in age from 18 to 38 years old, with the mean age of 22; and $71 \%$ of them were female. The majority of undergraduates and graduates were at public university (75\%), pursuing bachelor degree (59\%), and the sample was dominated by full time students ( $73 \%) .73 \%$ of those surveyed declared tourism studies to be their first choice and $47 \%$ of them had work experience in the tourism industry. Table 1 shows descriptive statistics for the sample.

Table 1. Respondent profile

\begin{tabular}{lcc}
\hline Variable & Category & Share [\%] \\
\hline \multirow{2}{*}{ Gender } & Female & 71.2 \\
& Male & 28.8 \\
\multirow{3}{*}{ Age } & 20 and less & 22.1 \\
& $21-22$ & 35.7 \\
& $23-24$ & 34.9 \\
\multirow{2}{*}{ First choice studies } & 25 and more & 7.3 \\
\hline \multirow{2}{*}{ Work experience in tourism } & Yes & 72.8 \\
& No & 27.2 \\
\multirow{2}{*}{ Study degree } & Yes & 47.1 \\
& No & 52.9 \\
\multirow{2}{*}{ Study mode } & Bachelor & 58.8 \\
& Master & 41.2 \\
\hline \multirow{2}{*}{ Year of study } & Full time & 72.8 \\
& Part time & 27.2 \\
\hline \multirow{2}{*}{ Type of school } & First & 18.9 \\
& Second & 8.4 \\
& Third & 25.3 \\
& Fourth & 18.3 \\
& Fifth & 29.1 \\
\hline
\end{tabular}

The data analysis involved descriptive statistics and correlations to portray the main features of variables under study and relations between them. In order to confirm the dimensionality of the questionnaire the factor analysis was performed. Chi-square and one-way analysis of variance (ANOVA) tests were employed to assess significant differences among groups. The statistical processing of the survey data was conducted using the SPSS software package. 


\section{Analysis}

To begin with, the results of dependent variable, i.e. attitude towards career in tourism, will be presented. As Figure 1 shows, over $60 \%$ of respondents treat tourism jobs are short-lived professions, with more than $10 \%$ intending not to start a career in the tourism industry at all. Only $11 \%$ of students plan long-term career in tourism.

Long-term career in tourism

Short-term career in tourism

No career in tourism

No opinion

\section{$11,0 \%$}

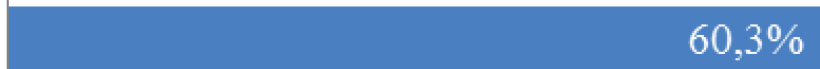

\section{$10,4 \%$}

\section{$18,3 \%$}

Figure 1. Attitudes towards career in tourism

Then, the influence of attractiveness of tourism employment on attitude towards career in tourism was examined. An exploratory factor analysis with varimax rotation was performed to reduce the number of variables. All 16 items loaded resulted in a four-factor structure, accounting for $67.7 \%$ of the total variance. Factors were labelled as economic benefits and development, social relations, job content and work-life fit, and customer relations. The results of the procedure are presented in Table 2.

Table 2. Summary of factor analysis

\begin{tabular}{lcc}
\hline Variable & $\begin{array}{c}\text { Number } \\
\text { of items }\end{array}$ & $\begin{array}{c}\text { Cronbach's } \\
\text { alpha }\end{array}$ \\
\hline 1. Economic benefits \& development & 6 & 0.870 \\
2. Social relations & 5 & 0.852 \\
3. Job content \& work-life fit & 4 & 0.704 \\
4. Customer relations & 1 & - \\
\hline
\end{tabular}

Basic statistics for the study variables are reported in Table 3. It presents means, standard deviations, and correlations among the computed gaps between preferred and perceived job/organisation attributes for generated constructs. The picture that emerges from the table is that students generally do not believe that a career in the tourism industry will offer them values 
they find desirable, economic benefits and development opportunities being the worst perceived dimension.

Table 3. Variable descriptive statistics and correlations

\begin{tabular}{|c|c|c|c|c|c|c|}
\hline \multirow{2}{*}{ Variable } & \multirow{2}{*}{ Mean } & \multirow{2}{*}{$\begin{array}{l}\text { Standard } \\
\text { deviation }\end{array}$} & \multicolumn{4}{|c|}{ Correlations } \\
\hline & & & 1. & 2. & 3. & 4. \\
\hline $\begin{array}{l}\text { 1. Economic benefits } \\
\text { \& development - gap }\end{array}$ & 0.7891 & 0.9324 & 1.00 & & & \\
\hline 2. Social relations - gap & 0.7513 & 0.9364 & $0.70^{* *}$ & 1.00 & & \\
\hline 3. Job content \& work-life fit - gap & 0.7683 & 0.9890 & $0.56^{* *}$ & $0.52 * *$ & 1.00 & \\
\hline 4. Customer relations - gap & 0.6429 & 1.4392 & $0.16^{*}$ & $0.17^{* *}$ & $0.17 * *$ & 1.00 \\
\hline
\end{tabular}

* Significant at the 0.05 level, ** significant at the 0.01 level (2-tailed).

It can be assumed that the negative image of the industry as an employer has a negative impact on plans for a career in tourism. In order to identify relations between tourism employment perceptions and intentions of students to pursue tourism careers, the one-way analysis of variance (ANOVA) was applied. The results of the analysis are shown in Figure 2.

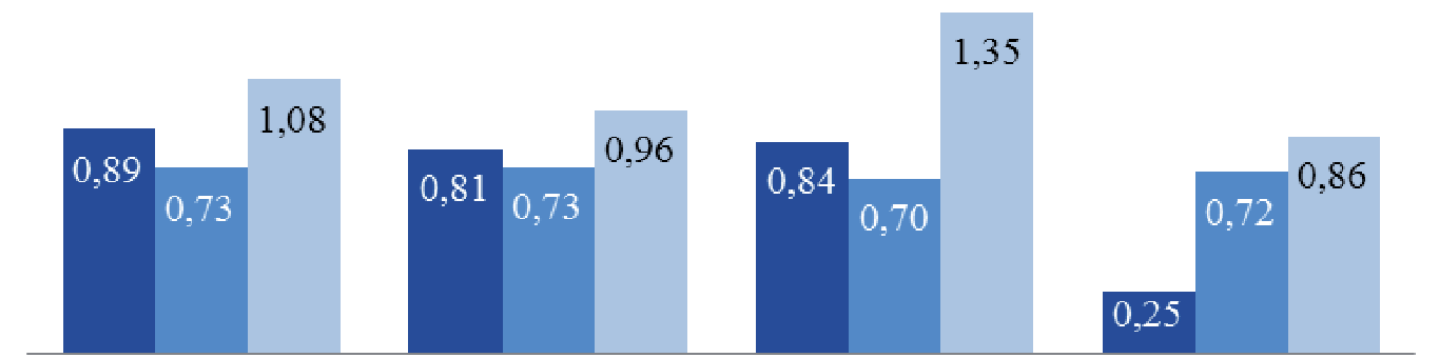

Economic benefits \& Social relations (ns) Job content \& work- Customer relations (*) development (ns) life fit $(*)$

- Long-term career in tourism $\square$ Short-term career in tourism $\square$ No career in tourism

$\left({ }^{*}\right)$ Significant at the 0.05 level; (ns) not significant.

Figure 2. Attitudes towards career and perception of tourism employment

With respect to hypothesis 1 , mixed evidence has been found. Significant differences in the perception of work concern two groups of variables: customer relations and job content \& work-life fit. Students planning longterm career in tourism evaluate customer relations significantly better than their colleagues not planning a career and those who treat work in tourism as transitory. Job content and work-life balance is also significantly better assessed by those who plan career in tourism than those who do not. 
The hypothesized negative effects of working experience on intentions to apply for a job in tourism have not found support in the data. Figure 3 shows that students who have been exposed to working life in tourism are significantly more committed to long-term career in the industry.

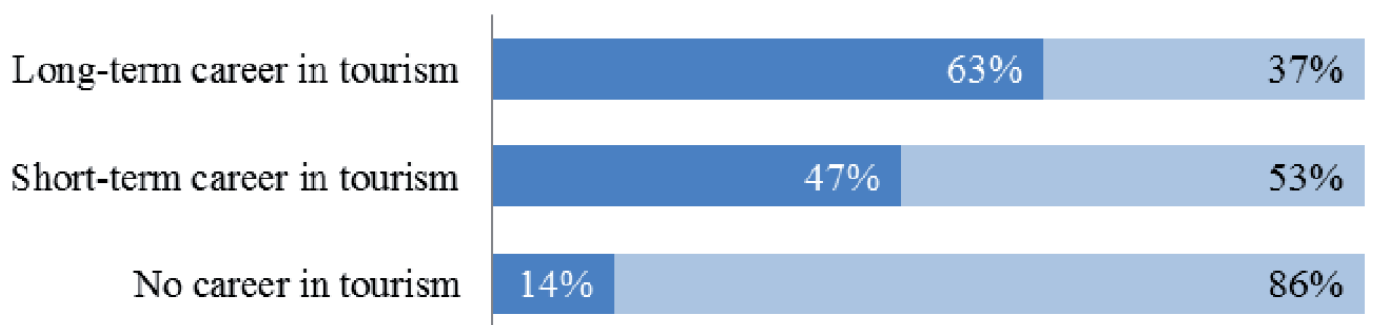

Working experience in tourism $\quad$ No working experience in tourism

Figure 3. Attitudes towards career and working experience in tourism

The third hypothesis was positively verified. Students who are satisfied with their studies are significantly more willing to undertake long-term career in tourism. As displayed in Figure 4, majority of students who plan career in tourism declare that they are satisfied with higher education.

Long-term career in tourism

Short-term career in tourism

No career in tourism

- High satisfaction with studies
$94 \% 6 \%$

$78 \%$ $22 \%$

$45 \%$ $55 \%$

Figure 4. Attitudes towards career and satisfaction with studies

Summarizing, as hypothesized, unfavourable image of tourism employment and dissatisfaction with studies have a negative impact on commitment to tourism careers. Unexpectedly, students with working experience in tourism are more interested in pursuing tourism-related jobs, thus the second hypothesis cannot be confirmed. 


\section{Discussion}

The research has investigated the impact of perception of tourism employment on students' attitude to work in tourism. The results of the study confirm previous findings indicating transitory nature of career in tourism (Jiang and Tribe, 2009; Kusluvan and Kusluvan, 2000; Richardson, 2010; Richardson and Butler, 2012; Duncan et al., 2013). However, the problem of limited loyalty towards employer concerns not only students of tourism and hospitality but is typical for entering the labour market representatives of generation $Y$. According to Solnet's research, the younger the employees, the more likely they are to quit unexpectedly (2011).

The findings of the study correspond also with those obtained in the course previous research, which highlighted that the negative image of the industry held by hospitality and tourism students caused them not to plan to pursue a job in tourism upon graduation or to leave the industry within a few years (King et al., 2003; Lu and Adler, 2009; Richardson, 2010; Maxwell, Ogden and Broadbridge, 2012). Another noteworthy result is that with the increase in the exposure to working life in the industry, students tend to be more committed to tourism careers. This is not in line with Roney and Oztin (2007), Koyuncu, Burke, Fiksenbaum and Demirer (2008), and Jiang and Tribe (2009), whose research revealed that work experience in the tourism industry led to deteriorated perception of working conditions and more pessimistic view on future job prospects in tourism. The present investigation also echoes previous observation that respondents' attitude to tourism studies is positively related to future employment opportunities perceptions (Roney and Oztin 2007).

Several practical implications of the investigation can be pointed out. First of all, tourism companies, striving for retention of the tacit knowledge, need to identify the expectations of employees and modify their working conditions to ensure they are receiving positive experiences while working. Bearing in mind that students represent generation $Y$, the employers should respond to their specific expectations. In accordance with numerous studies, they are looking to make a contribution to something worthwhile, to have their input recognized from the start, and they are used to fast outcomes and would not consider devoting years to developing their career. Moreover, they dislike menial and repetitive work and seek new challenges regularly (Cairncross and Buultjens, 2007; Solnet and Hood, 2008). The ability to create working environment that will induce employees' loyalty is a challenge for all employers of generation $Y$ workers. Employers should keep in mind that the most sought after organizational attributes by generation $Y$ graduates include heavy investment in training and development of employees, care about employees as individuals, variety in daily work, freedom to work on 
one's own initiative and scope for creativity in one's work (Solnet and Hood, 2008).

Of particular interest are the results concerning the impact of past work experiences on intention of taking up a long-term career in the tourism industry. Having them in mind tourism companies need to intensify their training programs to ensure students are receiving positive experiences while working during their degree. Moreover, they should modify their student placements offer, to put it in line with prospective employers expectations. Solnet's research highlights the importance of making a good first impression on new employees, particularly when they are in their first job (2011).

The results clearly indicate that students' satisfaction with the study fosters their decision to prolong their engagement in the tourism industry as an employee. Making study programs more attractive will therefore lead to the higher satisfaction with the study, and as a result reduce the knowledge leakage outside tourism sector. Universities should also increase students' practical training in order to give them more time to experience tourism jobs. On the other hand students should be made aware of working conditions in the tourism industry before they are enrolled. In order to reduce the gap between perception and expectations "students need to be informed about employment opportunities so that their career decisions are based on choice rather than chance" (Hing and Lomo, 1997, after: Kusluvan and Kusluvan, 2003, p. 96).

Undoubtedly, a limitation of this study is that it was carried out only at universities in one city in Poland. Although students are appropriate respondents for the study, due to unique characteristics of the population the results may not relate to a sample of other prospective employees who have more working experience and are at other stages of their careers. The nature of the sample limits generalizability of the results. Therefore, generalizations beyond the specific context of this research must be guarded. Thus, replication using a more diverse sample would be beneficial. Still to be examined is the degree to which the results could be confirmed for other target groups. Further studies are needed to verify or repudiate these findings within different contexts.

\section{Conclusion}

Growing recognition of the significance of tacit knowledge in gaining a competitive advantage has resulted in an intensified awareness amongst practitioners and researchers to better appreciate how to attract and retain employees who are "owners" of tacit knowledge. Taking this into account, continuous study of changing expectations of workers entering 
the labour market seems necessary, particularly as generation $Y$ represents distinct expectations from other groups. By investigating their employment expectations, companies would benefit from obtaining guidelines for the tacit knowledge management. This is due to the fact that the acquisition and retention of knowledge embedded in human minds requires attractive employment conditions which are in line with employee requests.

Tacit knowledge leakage can lead to adverse consequences for the employer, the employee and the education system, as:

- The theoretical knowledge (embrained knowledge), acquired during studies will not be completed and translated into practical knowledge (embodied knowledge);

- Investments made on the newly adopted employee are lost; knowledge and time spent on employee induction to the company are wasted;

- Graduates at the beginning of their career often change their career path, which is associated with inefficient educational resources allocation.

Practical implications for knowledge management concern: employees selection process, methods of knowledge protection, and methods of minimizing the costs of the loss of tacit knowledge. During the recruitment process, companies should select employees who are likely to treat tourism jobs as long lived professions, i.e. those who already have working experience in tourism, as well as those who are satisfied with their studies. Companies should strive to minimize the costs of knowledge loss by codification process and ongoing internal learning. Tacit knowledge can be preserved, in part, when firms promote employee interaction, collaboration, and diffusion of non-redundant tacit knowledge (Droege and Hoobler, 2003). Thus, tacit knowledge will contribute to gaining the competitive edge regardless temporary human capital outflow.

\section{References}

Almeida, P., Kogut, B. (1999). The localization of knowledge and the mobility of engineers in regional networks. Management Science, 45(7), 905-917.

Ambrosini, V., Bowman, C. (2008). Surfacing tacit sources of success. International Small Business Journal, 26(4), 403-431.

Argot, L., Ingram, P. (2000). Knowledge transfer: A basis for competitive advantage in firms. Organizational Behavior and Human Decision Processes, 82(1), 150-169.

Barney, J. (1991). Firm resources and sustained competitive advantage. Journal of Management, 17(1), 99-120. 
Barron, P.E., Maxwell, G.A. (1993). Hospitality management students' image of the hospitality industry. International Journal of Contemporary Hospitality Management, 5(5), 5-8.

Barron, P.E., Maxwell, G.A., Broadbridge, A., Ogden, S. (2007). Careers in hospitality management: Generation Y's experiences and perceptions. Journal of Hospitality and Tourism Management, 14(2), 119-128.

Baumard, P. (1999). Tacit knowledge in organizations. Thousand Oaks, CA: Sage Publications Ltd.

Bednarska, M., Olszewski, M. (2010). Postrzeganie przedsiębiorstwa turystycznego jako pracodawcy w świetle badań empirycznych. In: S. Tanaś (Ed.), Nauka i dydaktyka w turystce i rekreacji (pp. 277-286). Łódź: Łódzkie Towarzystwo Naukowe.

Blackler, F. (1995). Knowledge, knowledge work, and organizations: An overview and interpretation. Organization Studies, 16(6), 1021-1045.

Blomme, R., van Rheede, A., Tromp, D. (2009). The hospitality industry: An attractive employer? An exploration of students' and industry workers' perceptions of hospitality as a career field. Journal of Hospitality \& Tourism Education, 21(2), 6-14.

Cairncross, G., Buultjens, J. (2007). Generation Y and work in the tourism and hospitality industry: Problem? What problem? Centre for Enterprise Development and Research Occasional Paper, 9, 1-21.

Cooper, C. (2006)., Knowledge management and tourism. Annals of Tourism Research, 33(1), 47-64.

da Silva, M.A.P.M (2012). The knowledge multiplier. FEP Working Papers, 456, 1-27.

Davenport, T.H., \& Prusak, L. (1998). Working knowledge: How organizations manage what they know. Boston, MA: Harvard Business School Press.

Dickerson, J.P. (2009). The realistic preview may not yield career satisfaction. International Journal of Hospitality Management, 28(2), 297-299.

Droege, S.B., Hoobler, J.M. (2003). Employee turnover and tacit knowledge diffusion: A network perspective. Journal of Managerial Issues, 15(1), 50-64.

Duncan, T., Scott, D.G., Baum, T. (2013). The mobilities of hospitality work: An exploration of issues and debates. Annals of Tourism Research, 41, 1-19.

Filatotchev, I., Liu, X., Lu, J., Wright, M. (2011). Knowledge spillovers through human mobility across national borders: Evidence from Zhongguancun Science Park in China. Research Policy, 40(3), 453-462.

Gallupe, B. (2001). Knowledge management systems: surveying the landscape. International Journal of Management Reviews, 3(1), 61-77.

Granovetter, M. (1985). Economic action and social structure: The problem of embeddedness. American Journal of Sociology, 91(3), 481-510.

Hallin, C.A., Marnburg, E. (2008). Knowledge management in the hospitality industry: A review of empirical research. Tourism Management, 29(2), 366-381. 
Hjalager, A-M. (2002). Repairing innovation defectiveness in tourism. Tourism Management, 23(5), 465-474.

Hjalager, A-M. (2003). Global tourism careers? Opportunities and dilemmas facing higher education in tourism. The Journal of Hospitality Leisure Sport and Tourism, 2(2), 26-38.

Jiang, B., Tribe, J. (2009). 'Tourism jobs - short lived professions': Student attitudes towards tourism careers in China. Journal of Hospitality, Leisure, Sport and Tourism Education, 8(1), 4-19.

Kaj, U., Pekka, P., Hannu, V. (2003). Tacit knowledge acquisition and sharing in a project work context International. Journal of Project Management, 21(4), 281-290.

King, B., McKercher, B., Waryszak, R. (2003). A comparative study of hospitality and tourism graduates in Australia and Hong Kong. International Journal of Tourism Research, 5(6), 409-420.

Kogut, B., Zander, U. (1992). Knowledge of the firm, combinative capabilities, and the replication of technology. Organization Science, 3(3), 383-397.

Koyuncu, M., Burke, R.J., Fiksenbaum, L., Demirer, H. (2008). Predictors of commitment to careers in the tourism industry. Anatolia: An International Journal of Tourism and Hospitality Research, 19(2), 225-236.

Kusluvan, S., Kusluvan, Z. (2000) Perceptions and attitudes of undergraduate tourism students towards working in the tourism industry in Turkey. Tourism Management, 21(3), 251-269.

Leonard, D., Sensiper, S. (1998). The role of tacit knowledge in group innovation. California Management Review, 40(3), 112-132.

Lu, T., \& Adler, H. (2009). Career goals and expectations of hospitality and tourism students in China. Journal of Teaching in Travel \& Tourism, 9(1-2), 63-80.

Maxwell, G.A., Ogden, S.M., Broadbridge, A. (2012). Generation Y's career expectations and aspirations: Engagement in the hospitality industry. Journal of Hospitality and Tourism Management, 17(1), 53-61.

Nonaka, I. (1991). The knowledge-creating company. Harvard Business Review, 69, 96-104.

Nonaka, I. (1994). A dynamic theory of organizational knowledge creation. Organization Science, 5(1), 14-37.

Nonaka, I., Toyama, R., Nagata, A. (2000). A firm as a knowledge-creating entity: A new perspective on the theory of the firm. Industrial and Corporate Change, 9(1), 1-20.

Polanyi, M. (1966). The tacit dimension. London: Routledge. (University of Chicago Press. 2009 reprint).

Richardson, S. (2009). Undergraduates' perceptions of tourism and hospitality as a career choice. International Journal of Hospitality Management, 28(3), 382-388. 
Richardson, S. (2010). Generation Y's perceptions and attitudes towards a career in tourism and hospitality. Journal of Human Resources in Hospitality \& Tourism, 9(2), 179-199.

Richardson, S., Butler, G. (2012). Attitudes of Malaysian tourism and hospitality students' towards a career in the industry. Asia Pacific Journal of Tourism Research, 17(3), 262-276.

Roney, S.A., Öztin, P. (2007). Career perceptions of undergraduate tourism students: A case study in Turkey. Journal of Hospitality, Leisure, Sport and Tourism Education, 6(1), 4-17.

Solnet, D. (2011). Generation $Y$ as hospitality industry employees: An examination of work attitude differences. Queensland: The Hospitality Training Association and University of Queensland.

Solnet, D., Hood, A. (2008). Generation Y as hospitality employees: Framing a research agenda. Journal of Hospitality and Tourism Management, 15(1), 59-68.

Song, J., Almeida, P., Wu, G. (2003). Learning by hiring: When is mobility more likely to facilitate inter-firm knowledge transfer? Management Science, 49(4), 351-365.

Szivas, E., Riley, M., Airey, D. (2003). Labor mobility into tourism. Attraction and satisfaction. Annals of Tourism Research, 30(1), 64-76.

Tsoukas, H. (2003). Do we really understand tacit knowledge? In: M. EasterbySmith, M.A. Lyles (Eds.), The Blackwell handbook of organizational learning and knowledge management (pp. 411-427). Cambridge, MA: Blackwell Publishing.

Zack, M.H. (1999). Managing codified knowledge. Sloan Management Review, 40(4), 45-58.

Zucker, L.G., Darby, M.R., Armstrong, J. (1998). Geographically localized knowledge: spillovers or markets? Economic Inquiry, 36(1), 65-86.

\section{Abstrakt (in Polish)}

Skuteczne zarzqdzanie wiedzq ukryta wymaga zdolności przyciqgania i zatrzymania pracowników, którzy sq dysponentami tej wiedzy. Celem artykułu jest określenie nastawienia studentów wobec pracy w turystyce w kontekście zarzqdzania wiedzq ukrytq. Dzięki badaniom pierwotnym przeprowadzonym na grupie 351 studentów w Poznaniu wykazano, że przeważajqca ich większość nie planuje na stałe zwiqzać swojej kariery zawodowej z turystykq, co powodować może wyciek wiedzy poza sektor turystyki. Stwierdzono także, że nastawienie studentów wobec pracy w turystyce uwarunkowane jest ich wcześniejszymi doświadczeniami zawodowymi oraz satysfakcjq ze studiów.

Słowa kluczowe: wiedza ukryta, nastawienie wobec pracy, gospodarka turystyczna, studenci. 